\title{
DETERMINANTS OF YIELD GAP IN LOWLAND RICE PRODUCTION IN NORTH-CENTRAL NIGERIA.
}

\author{
${ }^{1}$ Akintayo, O.I, ${ }^{2}$ Rahji, M.A.Y, ${ }^{2}$ Awoyemi, T.T and ${ }^{2}$ Adeoti, A.I \\ ${ }^{1}$ Institute of agricultural research and training, Moor Plantation, Ibadan, Nigeria \\ ${ }^{2}$ Department of agricultural economics, University of Ibadan, Nigeria. \\ E-mail: oluremijay@yahoo.com
}

\begin{abstract}
Although Nigeria has comparative resource advantage in terms of favourable climatic, edaphic and ecological conditions in the production of rice, local production has not been able to meet the growing demand. The inability of the Nigerian rice economy to satisfy the domestic demand and the consequent growth of rice import quantity and value remains a cause of concern. The study analyzed the difference between potential and actual yield of rice in North Central Nigeria. Employing a multi-stage sampling technique, data were obtained through the use of structured questionnaire administered to a sample of one hundred and forty four rice farmers in Niger state, Nigeria. Data were analyzed using descriptive statistics and regression models. Results indicated that rice farmers in the area cultivated four improved rice varieties WITA 4, FARO 15, FARO 35 and FARO 44 with average yield gaps of 1.48, 2.85, 3.03 and 3.20 tons per hectare respectively. This makes these rice varieties under-exploited as farmers operate at levels where they obtain an average of $49 \%$ of the potential yield. Factors which contribute to the reduction in the magnitude of rice yield gap include increase in the frequency of contacts between farmers and extension workers, increase in fertilizer use per hectare and higher intensity of tractor use. It was recommended that the yield potential of cultivated rice varieties should be fully exploited as a first option to meeting the current level of national rice demand because increased rice production towards the attainment of self-sufficiency may well hinge upon the ability of farmers to narrow the gap between current rice yields and yield potentials.
\end{abstract}

Keywords: Lowland rice, Yield gap, Nigeria.

Corresponding author: Akintayo, O.I., Institute of Agricultural Research \& Training, P.O. Box 16478, Dugbe GPO, Ibadan, Oyo state, Nigeria. E-mail: oluremijay@yahoo.com

\section{INTRODCUTION}

Rice is an increasingly important crop in Nigeria and has been found to thrive under four main ecologies suitable for different rice varieties. These are: rain-fed upland, shallow swamps and inland valley swamps (rain-fed lowland), irrigated lowland and mangrove or tidal swamp ecology (Imolehin and Wada, 2005). Irrigated lowland accounts for ten to fifteen per cent of national rice production. However, rainfed lowland and upland ecologies constitute $80-85 \%$ of the national 
cultivated rice land and contribute $73-80 \%$ of total rice production. While these two rice ecologies (rainfed lowland and upland) have the potential to meet national demand, their average rice yield (1.8tons/ha) fall short of the expected national average yield of 5.0tons/ha and 3.0tons/ha respectively (Ogundele and Okoruwa, 2006).

Unlike irrigated lowland rice, rain-fed lowland rice is not characterized by a reliable and controlled external supply of water and a drainage system but rather depends solely upon rainfall and runoff (Zeigler and Puckridge, 1995). The soil surface under lowland rice ecology is flooded for at least part of the crop cycle and the maximum sustained flooding depth is less than $50 \mathrm{~cm}$ (Mackill et al, 1996). In Nigeria, the most important rice production system has been acknowledged to be the rainfed lowland (Akpokodje et al, 2001) which accounts for $43-53 \%$ of the total rice production (Imolehin and Wada, 2005; UNEP, 2005; Fashola etal, 2011).

Nigeria is known to have comparative resource advantage in terms of favourable climatic, edaphic and ecological conditions in the production of rice for self-sufficiency (Imolehin and Wada, 2005). The inability of the Nigerian rice economy to satisfy the domestic demand and the consequent growth of rice import quantity and value remains a cause of concern. This raises a number of pertinent questions. For instance, what factors explain the lag in domestic rice production?; What is the average rice yield in each agro-ecology in Nigeria?; What is the existing gap between potential and actual rice yield?. To provide answers to these questions, it is therefore important and of national interest to examine the yield gap and the factors which contribute to yield gap in rice production so as to pave the way for sustainable production of the crop and the attainment of self sufficiency in the crop.

Yield gap is the difference between potential and actual yields (Roetter, et al, 1998). Two exploitable components of yield gap have been recognized (Duwayri et al, 2000; Singh et al, 2001; Bhatia et al, 2006; Lobell et al, 2009). The first component is the difference between experimental station yields and potential farm yields which exists mainly because of environmental differences between experiment stations and the actual rice farms. The potential farm yield can be approximated by the yield obtained in on-farm experiments under non-limiting input condition. The second component of yield gap is the difference between the potential farm yield and the actual farm yield. The potential farm yield or the maximum attainable yield is the rice yield of on-farm plots with no physical, biological or economic constraints and with the best-known management practices for a given time in a given ecology (FAO, 2004). Narrowing yield gaps of rice not only increases rice yield and production, but also improves the efficiency of land and labour use, reduces production costs and increases sustainability (FAO,2004).

Researchers have examined rice yield gaps in Nigeria from different perspectives. For instance, Oladele and Somorin (2008) carried out a study on rice yield gap in Ogun state using technology gap (difference between on-farm-adaptive research yield and small plot adoption technique yield) and extension gap (difference between small plot adoption technique yield and actual farmers' yield)

Oladele and Sakagami (2005) examined the impact of extension services on national rice yield gap and found that extension intensity had significant impact on the reduction of rice yield gap 
in Nigeria. It has been noted (Siddiq, 2000) that potential yield of varieties varies with the ecology as well as the agro-climatic region. Therefore, precise knowledge on zone and ecosystem specific potential is a pre-requisite for meaningfully determining the untapped yield of the currently popular high yielding varieties. Exploitable yield gap cannot be defined in terms of national yield since the national yield is an average of yields of rice planted across agro-ecologies but in terms of farmers' yields in a particular location and season (Duwayri et al, 2000). Following Leocadio et al (2000), the yield gap considered in this study is the difference between potential farmers' yield and actual farmers' yield.

In order to design management interventions aimed at increasing rain-fed rice production, the magnitude of and variation in yield gaps associated with various constraining factors need to be assessed. Thus, the objective of this study is to evaluate the gap between potential farm yield and actual farm yield obtained for each variety of rice by farmers in lowland production system in north-central Nigeria. The second objective is to identify factors influencing the yield gap in the area of study.

\section{The Study Area}

\section{METHODOLOGY}

This study was carried out in Niger state, Nigeria. Located in the North-Central geopolitical and in the guinea savannah agro-ecological zones of Nigeria, it is situated between latitudes $8^{\circ} 20$ and $11^{\circ} 30$ north and longitude $3^{\circ} 80$ and $7^{\circ} 20$ east. Niger state is the largest state in Nigeria, representing approximately $9.3 \%$ of the total land area of the country (http://dap.nigerstateonline.com). With a land area of 76.363 square kilometers and a population of 4,082,558 (2005 estimate), Niger state shares borders with the republic of Benin in the west, Zamfara state in the north, Kebbi state in the northwest,, Kogi state in the south, Kwara state in the southwest, Kaduna state in the northeast and the Federal Capital Territory (FCT) in the southeast. Agricultural activities form the mainstay of the peoples' economy and engage more than eighty per cent of the population. The state has an annual precipitation of about $1250 \mathrm{~mm}$ and a mono-modal rainfall distribution. Major crops cultivated in Niger state include rice, yams, sorghum, maize, groundnuts, sugarcane, melon and millet. Niger state is one of the three states (Niger, Kaduna and Taraba) in Nigeria which have the largest rice area of between 184,000 and 230,000 hectares. Administratively, the state has twenty-five local government areas (http://dap.nigerstateonline.com/DAP1_Introduction.pdf)

\section{Sampling Procedure and Data Collection}

Amulti-stage sampling technique was employed in collecting the data for the study.

Niger state was purposively selected for this study because of its predominant lowland rice ecology. The first stage of sampling was the random selection of two out of the three Agricultural Development Programme (ADP) zones. Secondly, eight rice producing local government areas were then randomly selected from the two ADP zones. The third stage involved the random selection of twelve rice-producing villages from the selected eight local government areas while 
the fourth stage was the random selection of one hundred and forty-four (144) rice farmers from the selected villages.

\section{Methods of Data Analysis}

Descriptive statistics: Measures such as percentages, frequencies, means and standard deviations were used in the description of characteristics of rice farms inputs used in the production of rice. Data from the study were fitted into three models (semi-log, double log and simple linear regression models). Based on the resulting R-square for each model, the simple linear regression model was chosen, having the highest $R$-squarevalue.

Linear regression was employed to determine the factors that affect rice yield gap.

Model specification for the linear regression: $Y=f\left(X_{1}, x_{2}, x_{3}, X_{4}\right.$, $\left.\mathrm{X}_{13}\right)$

$\mathrm{Y}=$ Yield gap

$X_{1}=$ number of years of schooling

$\mathrm{X}_{2}=$ Household size (number of people)

$\mathrm{X}_{3}=$ experience in rice farming (years)

$\mathrm{X}_{4}=$ participation in non-farm income activities ( $0=$ non-participation; $1=$ otherwise $)$

$X_{5}=$ distance between farm and market (Kilometers)

$X_{6}=$ number of extension visits

$X_{7}=$ Use of tractor and other implements

$\mathrm{X}_{8}=$ labour/ha (mandays)

$X_{9}=$ seed $/ \mathrm{ha}(\mathrm{kg})$

$X_{10}=$ fertilizer/ha $(\mathrm{kg})$

$X_{11}=$ agrochemicals/ha (liters)

$X_{12}=$ commercialization level (Percentage of total output sold)

$X_{13}=$ proportion of total land cultivated to rice (Percentage)

\section{RESULTS AND DISCUSSION}

All the farmers cultivated improved rice varieties, but these varied between farmers. Seventeen (16.56\%) per cent of the farmers cultivated FARO 15 variety, three $(3.31 \%)$ per cent cultivated FARO 35 variety, twenty-six per cent $(26.49 \%)$ cultivated FARO 44 and fifty-four (53.64\%) per cent cultivated WITA4 variety. This confirms the finding of Ojehomon et al (2006) who reported that the adoption rate of improved rice varieties by farmers in Niger state was high, with varieties varying across villages. Yield gap for each rice variety was evaluated based on the difference between the actual yield and the potential yield. That is, yield gap is taken to be the mean potential yield minus mean farm yield. The potential yield of FARO 15 has been given to be between 3.0 and 5.5t/ha while that of FARO 35 is between 3.0 and 6.5t/ha (Imolehin and Wada, 2005). FARO 44 has potential yield between 4.0 and 6.0 t/ha and WITA 4 has an average potential 
yield of 3.8tha. (Imolehin and Wada (2005), WARDA(2008).

On the average, the lowland rice varieties cultivated in this study, attained about half $(48.92 \%)$ of the potential yield. This is similar to the report of Ojehomon et al (2006) who stated that lowland rice farmers in Niger state obtained only $50 \%$ of the expected rice yield as a result of non/partial adoption of recommended management practices. However, in the study of Ojehomon et al (2006), all the rice varieties cultivated by the farmers were aggregated. With regards to individual rice varieties in this study, FARO 15, FARO 35, FARO 44 and WITA 4 attained $32.87 \%$, $36.13 \%, 35.91 \%$ and $61.09 \%$ of their potential yield respectively. As illustrated on Table 1, yield gap was highest for FARO 44 variety with 3.20 tons per hectare and lowest for WITA 4 variety with a yield gap of 1.48 tons per hectare. These yield gaps could be attributed partly to the sub-optimal levels of technical inputs applied to the different rice varieties by the farmers as illustrated on Table 2 which shows the input quantity and the proportion of the recommended optimum quantity used perhectare.

Lowland rice farmers in the study area planted between eleven and sixty-three per cent of the recommended seed rate per hectare. In addition, fertilizers applied to rice farms were between thirty-six and fifty-nine per cent of recommended quantities while agrochemicals applied were between ten and twenty-one per cent of recommended quantities. This is in agreement with the findings of Fatoba et al (2009) who reported that low fertilizer application rates could account for part of the high yield gap in wetland rice production in Nigeria.

Co-linearity diagnosis was carried out and result gave VIF (variance inflation factor) values of less than 5. The variance inflation factor shows how much the variance of the coefficient estimate is being inflated by multicollinearity. VIF values of less than ten are no reasons for concern (O'Brien, 2007). Thus, the results of the simple linear regression analysis are discussed. Results from the regression analysis (Table 3 ) indicate that farmers' educational level $\left(X_{1}\right)$ and household size $\left(X_{2}\right)$ had no significant effect on the magnitude of rice yield gap. Farmers' experience in rice farming $\left(X_{3}\right)$ had some significant reducing-influence on the size of rice yield gap. Non-farm income $\left(X_{4}\right)$ had no significant effect on rice yield gap. In other words, the engagement in non-farm income-generating activities by farmers contributed insignificantly to the magnitude of rice yield gap. Distance between farmers' homestead and rice farm $\left(X_{5}\right)$ had significant effect on the rice yield gap magnitude. Extension visits $\left(X_{6}\right)$ also had significant effect on the size of rice yield gap. This implies that the more visits farmers received form extension workers for technical education/assistance, the lower the yield gap would be. The use of farm machines and implements $\left(X_{7}\right)$ represented in this study by tractor and knapsack, had significant reducing-effect on rice yield gap. This implies that the more of tractor (for land preparation) and knapsack (for spraying of chemicals) the farmers use, the narrower the rice yield gap would be. The significant influence of labour use per hectare $\left(X_{8}\right)$ on yield gap can be explained to be due to the sub-optimal use of agrochemicals especially herbicides. Thus, human labour is used to accomplish the task of the herbicides. Seeds $\left(X_{g}\right)$ and agrochemicals $\left(X_{11}\right)$ had non-significant effects on yield gap size while fertilizers $\left(X_{10}\right)$ had some significant 
reducing-effects. Commercialization level $\left(X_{12}\right)$ had significant effect on the narrowing of yield gap. This indicates that the more market-oriented a lowland rice farm is, the narrower the yield gap would be. The proportion of total landholding cultivated to rice by farmers had no significant influence on rice yield gap in the study area.

However, it is important to note that yield gap is a dynamic concept and so are the factors which influence it (Oladele and Sakagami, 2005). Therefore, certain factors which have no significant influence on size of yield gap in a particular season may turn out to have significant effects at other seasons in the same location.

\section{CONCLUSIONS}

All rice farmers in the study cultivated improved rice varieties but employed sub-optimal recommended management practices. Seed rate, fertilizers and agrochemicals were applied by the rice farmers at rates which were sub-optimal with regards to the recommended rates of WARDA. Yield obtained by rice farmers fall short of expected yield of the improved varieties cultivated. There is considerable scope for increased rice yield in the lowland rice ecology through the exploitation of its high potential for intensification. It is important that farmers' constraints to high rice yields be well understood and farmers provided with appropriate technological packages designed for their specific rice varieties and ecology. Farmers should also be given necessary training and demonstrations by appropriate extension service agents on correct use of recommended technological packages in order to make significant contributions to narrowing down rice yield gap. The yield potential of cultivated rice varieties should be fully exploited as a first option to meeting the current level of national rice demand because increased rice production towards the attainment of self-sufficiency may well hinge upon the ability of farmers to narrow the gap between current rice yields and yield potentials.

\section{REFERENCES}

Africa Rice Center (WARDA), FAO and SAA(2008). NERICA: The new rice for Africa A compendium. Somado, E.A, Guei, R.G and Keya, S.O (Eds) Cotonou, Benin: Africa Rice center (West Africa rice development Association, WARDA); Rome, Italy: FAO; Tokyo, Japan: SasakawaAfrica Association. 210pp.

Akpokodje, G., Lancon, F \& Erenstein, 0 (2001). Nigerials rice economy: State of the Art. USAID Project report on the Nigerian rice economy in a competitive world:Constraints, opportunities and strategic choices. West Africa rice development Association (WARDA), Bouake, Cote d'Ivoire. 
Bhatia V.S., Singh P., Wani S.P., Kesava Rao A.V.R and Srinivas K.(2006). Yield gap analysis of soybean, groundnut, pigeonpea and chickpea in India using simulation modeling. Global theme on agroecosystems Report no. 31. International Crops Research Institute for the Semi-Arid Tropics (ICRISAT). 156 pp.

Duwayri, M., Tran, D.V.and Nguyen, V. N. (2000). "Reflections on Yield Gaps in Rice Production: How to Narrow the Gaps". In Papademetriou, M.K., Dent, F.J., Herath, E.M. (Eds), Bridging the Rice Yield Gap in the Asia-Pacific Region, FAO, RAP Publication: 2000/16.

FAO (2004). Rice and narrowing the yield gap Retrieved December 10, 2010 from, www.fao.org/rice2004/en/factsheet5.pdf

Fashola 0. O. , G. O. Olaniyan, J. Aliyu \& T. Wakatsuki (2011). Water Management Practices for Sustainable Rice Production in Nigeria. Retrieved April 27, 2011 from, www.kinki-ecotech.jp/download/kiban5/NiRiceMemo.pdf

Fatoba, I.O., Omotesho, O.A. and Adewumi, M.O (2009). Economics of wetland rice production technology in the guinea savannah of Nigeria. Journal of development and agricultural economics 1(9): 199-203.

Imolehin, E.D and Wada, A.C. (2005). Meeting the rice production and consumption demands of Nigeria with improved technologies. International rice commission newsletter vol 49 FAO, Rome.

Gupta, P.C and Otoole, J.C (1986). Upland rice:A global perspective. International rice Research institute, Los Banos, Laguna, Philippines. 358pp.

Lobell, D.B, Cassman, K.G and Field, C.B. (2009). Crop yield gaps: Their importance, magnitudes, and causes. Annual review of environment and resources 34:179-204.

O'Brien, R.M (2007). Acaution regarding rules of thumb for variance inflation factors. Quality and quantity 41:673-690.

Ogundele, 0.0 \& Okoruwa, V.O (2006). Technical Efficiency Differentials in Rice Production Technologies in Nigeria. AERC Research Paper 154. African Economic Research Consortium, Nairobi, Kenya.

Ojehomon, V.E.T., Abo, M.E., Ojehomon, 0 and Ukwungwu, M.N (2006). Adoption of recommended management practices in the lowland rice ecology of Niger state, Nigeria. Tropicultura 24:2 82-89. 
Oladele O. I. and Sakagami, J. I. (2004). Impact of technology innovation on rice yield gap in Asia and West Africa: Technology transfer issues Retrieved April 16, 2009, from http://www.tropentag.de/2004/abstracts/full/2.pdf

Oladele, O.I. \& Somorin, A.B (2008). Technology and extension gaps among rice farmers in Ogun state, Nigeria. Agricultura tropica et subtropica 41(4):160-164.

Singh, P.,Vijaya, D., Chinh, N.T., Pongkanjana,A., Prasad, K.S., Srinivas, K., \& Wani, S.P. (2001). Potential productivity and yield gap of selected crops in the rainfed regions of India, Thailand, and Vietnam. Natural Resource Management Program Report no. 5. International Crops Research Institute for the Semi-Arid Tropics. 50 pp.

Roetter, R.P., Aggarwal, P.K., Tan, P.S., Hoanh, C.T., Cabrera, J.M.C.A. \& Nunez,B., (1998). Use of crop simulation models and altenative yield estimation techniques for optimizing agricultural land use and resource management. In Roetter, R.P., Hoanh, C.T., Luat, N.V., Van Ittersum, M.K. and Van Laar, H.H. (Eds), Exchange of methodologies in land use planning, SysNet Research Paper Series No. 1, IRRI, Los Baños, Philippines, 15-29.

Siddiq, E.A. (2000). Bridging the rice yield gap in India. Retrieved November 11, 2010 from www.fao.org/docrep/003/x6905e/x6905e09.htm.

UNEP (2005). Integrated Assessment of the Impact of Trade Liberalization: A Country Study on the Nigerian Rice Sector. 107pp. United nations environment programme. Retrieved February 16, 2009 from www.unep.org. 
Table 1: Mean Farm Yield, Yield Gap and Potential Yield of Rice Varieties Cultivated by Respondents.

\begin{tabular}{llll}
\hline Rice variety & Mean Potential yield (t/ha) & Mean farm yield (t/ha) & Mean yield gap (t/ha) \\
& & & \\
\hline FARO 15 & 4.25 & 1.39 & 2.85 \\
FARO 35 & 4.75 & 1.72 & 3.03 \\
FARO 44 & 5.00 & 1.79 & 3.20 \\
WITA 4 & 3.80 & 2.32 & 1.48 \\
Total & & 2.01 & 2.21 \\
\hline
\end{tabular}

Source: Field data

Table 2: Mean Technical input use per hectare according to Rice Varieties

\begin{tabular}{llll}
\hline Input/variety & Quantity/ha & Standard deviation & $\begin{array}{l}\text { Percentage of } \\
\text { recommended } \\
\text { quantity used }\end{array}$ \\
\hline Seed (kg) & & & \\
& & & 11.62 \\
FARO 15 & 6.97 & 4.40 & 11.72 \\
FARO 35 & 7.03 & 2.55 & 62.48 \\
FARO 44 & 37.49 & 37.39 & 62.48 \\
WITA 4 & 37.49 & 31.85 & 52.38 \\
Total & 31.43 & 32.51 & \\
& & & \\
Fertilizers (kg) & & & 52.30 \\
& & 34.80 & 58.22 \\
FARO 15 & 156.9 & 34.77 & 36.85 \\
FARO 35 & 174.67 & 62.44 & 48.09 \\
FARO 44 & 110.56 & 84.81 & 46.15 \\
WITA 4 & 144.29 & 73.50 & \\
Total & 138.45 & & 17.11 \\
& & & 20.11 \\
Agrochemicals (liters) & & 10.78 \\
FARO 15 & 1.54 & 0.37 & 20.22 \\
FARO 35 & 1.81 & 0.27 & 17.22 \\
FARO 44 & 0.97 & 0.89 & \\
WITA 4 & 1.82 & 1.40 & \\
Total & 1.55 & 1.19 & \\
\hline
\end{tabular}

Source: Field data 
Table 3: Regression Estimates for factors affecting Rice Yield Gap

\begin{tabular}{llll}
\hline Variable & Coef. & Std Err & t-stat \\
& & & \\
\hline Years of schooling & -0.022 & 0.024 & -0.94 \\
Household size & 0.102 & 0.083 & 1.23 \\
Rice farming experience & -0.174 & 0.092 & $-1.89^{*}$ \\
Non-farm income activity & -0.132 & 0.164 & -0.81 \\
Distance between farm and market & -0.416 & 0.097 & $-4.28^{* * *}$ \\
Extension visits & -0.037 & 0.019 & $-1.94^{*}$ \\
Tractor and implement use & -0.113 & 0.058 & $-1.96^{* *}$ \\
Labour & -0.249 & 0.080 & $-3.10^{* * *}$ \\
Seed & -0.042 & 0.069 & -0.60 \\
Fertilizers & -0.033 & 0.019 & $-1.67^{*}$ \\
Agrochemicals & -0.008 & 0.015 & -0.55 \\
Commercialization level & -1.064 & 0.475 & $-2.24^{* *}$ \\
Rice land proportion & -0.191 & 0.145 & -1.32 \\
K & 16.527 & 2.062 & 8.02 \\
R2 & 0.5125 & & \\
F & 10.59 & & \\
\hline
\end{tabular}

${ }^{*}$ significant at $10 \%,{ }^{* *}$ significant at $5 \%,{ }^{* * *}$ significant at $1 \%$ 